\title{
From Dust Bowl to Dust Bowl: Soils are Still Very Much a Frontier of Science
}

\section{Philippe C. Baveye*}

Lab. of Soil and Water Engineering

Dep. of Civil and Environmental Engineering

Rensselaer Polytechnic Institute

Troy, NY 12180

and

SIMBIOS Centre

Abertay Univ.

Kydd Bldg., 40 Bell St.

Dundee DD1 1HG, Scotland, UK

\section{David Rangel}

Lab. of Soil and Water Engineering

Dep. of Civil and Environmental

Engineering

Rensselaer Polytechnic Institute

Troy, NY 12180

\section{Astrid R. Jacobson}

Plants, Soils and Climate Dep.

Utah State Univ.,

4820 Old Main Hill

Logan, UT 84322-4820

\section{Magdeline Laba}

Institute for Resource Information

Sciences,

Bradfield Hall, Cornell Univ.

Ithaca, NY 14850

\section{Christophe Darnault}

Hydromechanics and Water Resources Engineering Lab.

Dep. of Civil and Materials Engineering (MC 246)

Univ. of Illinois at Chicago

842 W. Taylor St.

Chicago, IL 60607-7023

\section{Wilfred Otten}

SIMBIOS Centre

Abertay Univ.

Kydd Bldg., 40 Bell St.

Dundee DD1 1HG, Scotland, UK

\section{Ricardo Radulovich}

Dep. of Agricultural Engineering

Univ. of Costa Rica

San Jose, Costa Rica

\section{Flavio A. O. Camargo}

Lab. of Soil Microbiology

Dep. of Soils

Federal Univ. of Rio Grande do Sul

Bento Goncalves, Porto Alegre

RS, Brazil

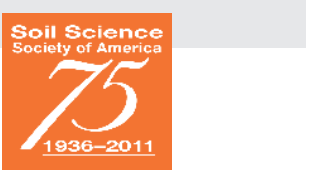

When the Soil Science Society of America was created, 75 yr ago, the USA was suffering from major dust storms, causing the loss of enormous amounts of topsoil as well as human lives. These catastrophic events reminded public officials that soils are essential to society's well-being. The Soil Conservation Service was founded and farmers were encouraged to implement erosion mitigation practices. Still, many questions about soil processes remained poorly understood and controversial. In this article, we argue that the current status of soils worldwide parallels that in the USA at the beginning of the 20th century. Dust bowls and large-scale soil degradation occur over vast regions in a number of countries. Perhaps more so even than in the past, soils currently have the potential to affect populations critically in several other ways as well, from their effect on global climate change, to the toxicity of brownfield soils in urban settings. Even though our collective understanding of soil processes has experienced significant advances since 1936, many basic questions still remain unanswered, for example whether or not a switch to no-till agriculture promotes $\mathrm{C}$ sequestration in soils, or how to account for microscale heterogeneity in the modeling of soil organic matter transformation. Given the enormity of the challenges raised by our (ab)uses of soils, one may consider that if we do not address them rapidly, and in the process heed the example of U.S. public officials in the 1930s who took swift action, humanity may not get a chance to explore other frontiers of science in the future. From this perspective, insistence on the fact that soils are critical to life on earth, and indeed to the survival of humans, may again stimulate interest in soils among the public, generate support for soil research, and attract new generations of students to study soils.

W Then the Soil Science Society of America (SSSA) was created on 18 Nov. 1936, through the merger of the American Soil Survey Association and the soils section of the American Society of Agronomy (Albrecht, 1937), soils had been more than just on the mind of people in the United States in the few preceding years. In vast sections of the country, as a result of what has since been referred to as the "Dust Bowl" (Joel, 1937) of the "dirty thirties", soil dust was ubiquitous in their kitchens, bedrooms and living rooms, in the sandwiches they ate, in the air they breathed, and, tragically, in the lungs of those who died of "dust pneumonia".

The unfolding of this human and environmental tragedy has been recounted recently in a number of captivating books (Egan, 2006; McDunn, 2007; Montgomery, 2007; Marrin, 2009). Just 3 yr before the creation of the SSSA, on 11 Nov. 1933, a major dust storm provided a foretaste of many "black blizzards" to follow. It swept through South Dakota, causing some farms to lose all their topsoil in a single day. The next morning, the sky in the region remained dark until noon. Six months later, on 9 May 1934, high winds ripped up overplowed fields and overgrazed pastures in Montana and Wyoming. Blowing across the Dakotas, the storm picked up an estimated 300 million tons of topsoil, and continued moving eastward, choking people, shredding crops, and killing livestock along the way. The next day, Buffalo, in western New York, fell dark at noon. At dawn on May 11th, large amounts of dust settled on New York City, Boston, and Washington, DC. The following spring, windstorms again tore through parched fields in Kansas, Texas, Colorado, Oklahoma, and Nebraska. On 2 Apr. 1935, as a Senate Public

Soil Sci. Soc. Am. J. 75:2037-2048

Posted online 28 Sept. 2011

doi:10.2136/sssaj2011.0145

Received 18 Apr. 2011.

*Corresponding author (baveyp@rpi.edu).

(C) Soil Science Society of America, 5585 Guilford Rd., Madison WI 53711 USA

All rights reserved. No part of this periodical may be reproduced or transmitted in any form or by any means, electronic or mechanical, including photocopying, recording, or any information storage and retrieval system, without permission in writing from the publisher. Permission for printing and for reprinting the material contained herein has been obtained by the publisher. 
Lands Committee on Capitol Hill was pondering the need for a national soil conservation program, a huge storm blew in from the plains, causing the sky to go dark in the middle of the day. On 14 Apr. 1935, known as "Black Sunday", the biggest dust storm on record descended over five states, from the Dakotas to Amarillo, TX. People standing a few feet apart could not see each other; if they touched, they risked being knocked over by the static electricity that the dust created in the air (Egan, 2006).

Black blizzards stopped after 1936, generally, but smaller dust storms still occurred until 1940 in particular areas. At that point, the chief of the newly established Soil Conservation Service expressed the viewpoint that the dust storm of May 1934 had been a turning point in terms of the public's awareness of the problem: "when people along the seaboard of the eastern United States began to taste fresh soil from the plains 2000 miles away, many of them realized for the first time that somewhere something had gone wrong with the land" (cited by Montgomery, 2007). As a result, the public and the federal government began to see soil conservation as an issue of national survival. In that spirit, Harper (1937) wrote of the need to "discover a system of cooperation which will maintain a productive soil to keep our civilization viable, healthy, and permanent." On 26 Feb. 1937, in a letter to all state governors on a Uniform Soil Conservation Law, President Roosevelt wrote the often-quoted motto "The nation that destroys its soil destroys itself."

Perhaps the clearest expression of the fact that the crucial importance of soils to society's survival was becoming increasingly recognized at about the time the SSSA was created, is to be found in a foreword written by H.A. Wallace, then U.S. Secretary of Agriculture, to a voluminous collective book on soils, suggestively titled "Soils and Men" (USDA, 1938). He wrote: "The earth is the mother of us all, plants, animals and man. [...] Nature treats the earth kindly. Man treats her harshly. He overplows the cropland, overgrazes the pastureland, and overcuts the timberland. He destroys millions of acres completely. The flood problem, insofar as it is man-made, is chiefly the result of overplowing, overgrazing, and overcutting of timber. [...] This terribly destructive process is excusable in a young civilization. It is not excusable in the United States in the year 1938. [...] We know what can be done and we are beginning to do it. [...] The public is waking up, and just in time. In another $30 \mathrm{yr}$ it might have been too late. [...] The social lesson of soil waste is that no man has the right to destroy soil even if he does own it in fee simple. The soil requires a duty of man which we have been slow to recognise."

Certainly, as indicated by Secretary Wallace, soil conservation measures required to prevent the massive soil erosion of the late 19 th century and early decades of the 20th century were known in the 30 s, and had indeed been known since time immemorial. Soil properties and climatic conditions making soils vulnerable to erosion were also known. For example, as mentioned by Hillel (1992), the USGS had concluded in 1902, in its 22nd annual report, that the semiarid High Plains from Nebraska to Texas were fatally vulnerable to rapid erosion if plowed: "The High Plains [...] are held only by their sod." The report warned that the regional rainfall was too low to support crops consistently and that once stripped of sod, the loess soil would not remain in place under the high winds and pounding rains of the open prairie. The only long-term use they could recommend for the "hopelessly non-agricultural region" was grazing. Had this advice been followed, the dust bowl of the 1930 s could have been largely prevented.

As soon as conservation measures were implemented and the drought conditions eased, in the following years, soil erosion began to decrease dramatically and dust storms ceased entirely. When the next drought cycle hit (in the 1950s), there was no repeat of the dust bowl. Yet, even though enough practical knowledge of soils was available to devise appropriate conservation measures, numerous detailed aspects of soils were still very poorly understood, and often contentious. For example, two very opposite perspectives were held concerning the nature of the clay fractions of soils (Grim, 1968; Cady and Flach, 1997). One perspective, based on x-ray diffraction analyses (Hendricks and Fry, 1933), was that most soil materials, even in their finest size fractions, were composed of crystalline particles. Another viewpoint, advocated chiefly by Mattson (1929) was that the colloid complex was made up of a relatively inert framework of silica, iron, and aluminous materials encased in an active amorphous envelope (Grim, 1968). The U.S. Bureau of Soils espoused the latter viewpoint, which was also manifested implicitly in Marbut's celebrated Atlas of Soils of the United States (Marbut, 1935). This atlas contained more than 200 mechanical and chemical analyses of complete soil profiles, but did not provide any information about the composition of clay minerals in any of these soils! It took another $20 \mathrm{yr}$, until the early 1950s, for the debate on the amorphous/crystalline nature of the clay fraction of soils to be resolved (basically by showing that both perspectives were correct, depending on the soils considered).

Another example of lack of understanding of, and disagreement among scientists on, soil properties concerned the mechanisms responsible for soil acidity, which in the 1930s remained very elusive. Soil scientists were divided into two camps, one claiming that soil acidity was the result of soil aluminum, whereas the other considered that soil acidity resulted from exchangeable $\mathrm{H}^{+}$. This issue had to await the research of Coleman and Harward (1953), some 20 yr later, to finally be resolved. A final example of controversy, still of great relevance today, is related to the humus content of soils. Marbut (1935) did not provide any data on humus content (or any acidity-related parameter, either), for any of the soils he analyzed and described in his landmark atlas. This is in sharp contrast with the fact that a number of researchers in the USA, in particular Waksman at Rutgers, had published humus-related articles for well over a decade (Krupenikov, 1993). Just a few months after the publication of Marbut's (1935) atlas, Waksman (1936) published a major monograph on humus in which he stressed its great significance in nature and especially in soils...

This rapid overview of the status of soils in the 1930s suggests that there was a definite public awareness that soils were crucial to the well-being and even survival of society, and that at the same time much about soils was unknown. To the best of 
our knowledge, no one at the time ever referred to soils as a "final frontier", a label that, in retrospect, would have fit extremely well with the opinions expressed. The concept of "final frontier" itself emerged only in the 1960s, and is now typically associated with an issue or topic that is, simultaneously, perceived as still largely to be explored, and to some extent essential to the survival of mankind, with the word "final" implying tacitly that there can be only one such frontier at any given time. It is widely acknowledged that the idea of a final frontier was made popular by the science fiction television series Star Trek, telecast in the United States and southern Canada during the second half of the 1960s. William Shatner's voice-over introduction during each episode's opening credits states the starship's purpose as "Space: the final frontier. These are the voyages of the starship Enterprise. Its 5-yr mission: to explore strange new worlds, to seek out new life and new civilizations, to boldly go where no man has gone before." For a long time following the peak of popularity of the Star Trek series, the idea of a "final frontier" remained intimately associated with space exploration (Genta and Rycroft, 2006; Bainbridge, 2009). However, in the last decade, with the prospect of exploring other planets becoming ever more distant, the concept of final frontier seems to have become up for grabs in just about any context imaginable. For some researchers, for example, silicon lasers are the final frontier (Jenkins et al., 2007). Other authors have no qualms associating the concept with topics as esoteric as, for example, the "transaortic fine-needle aspiration of centrallylocated lung cancer under endoscopic ultrasound guidance" (Wallace et al., 2007).

Among this plethora of appropriations of the concept of final frontier for a wide variety of purposes, a few articles have put forth that soils, or at least some of their characteristics (e.g., Ramanathan et al., 2006; Paungfoo-Lonhienne et al., 2010), should be considered "the" genuine final frontier. A 1995 feature article in The Independent, for example, advocated that the biodiversity of soils is essential to mankind, yet most of the life forms present in soils are still utterly unknown: "we are left with a living world of which we know next to nothing. [...] The thought is shocking to a generation brought up to believe that space was the final frontier. Suddenly, we discover, the earth beneath our feet is an alien planet." (Appleyard, 1995). In June 2004, the journal Science devoted the cover of one its issues to "Soils: The final frontier" (Fig. 1), a catchy title that has attracted considerable attention (e.g., Baveye et al., 2006). The lead article of this issue of Science emphasizes the need for subterranea to "seem far less of an alien experience" (Sugden et al., 2004). However, neither Appleyard (1995) nor the various articles in the special issue of Science articulate in any detail why the label of "final frontier" still applies to soils at this stage, nor what practical or strategic advantage may be gained by this labeling at this juncture.

In this context, the objectives of the present article are, first, to describe succinctly a number of situations around the globe in which soils appear crucial to the well-being of large segments of the population. Then, we show with several concrete examples that, in spite of remarkable progress in our understanding of soil

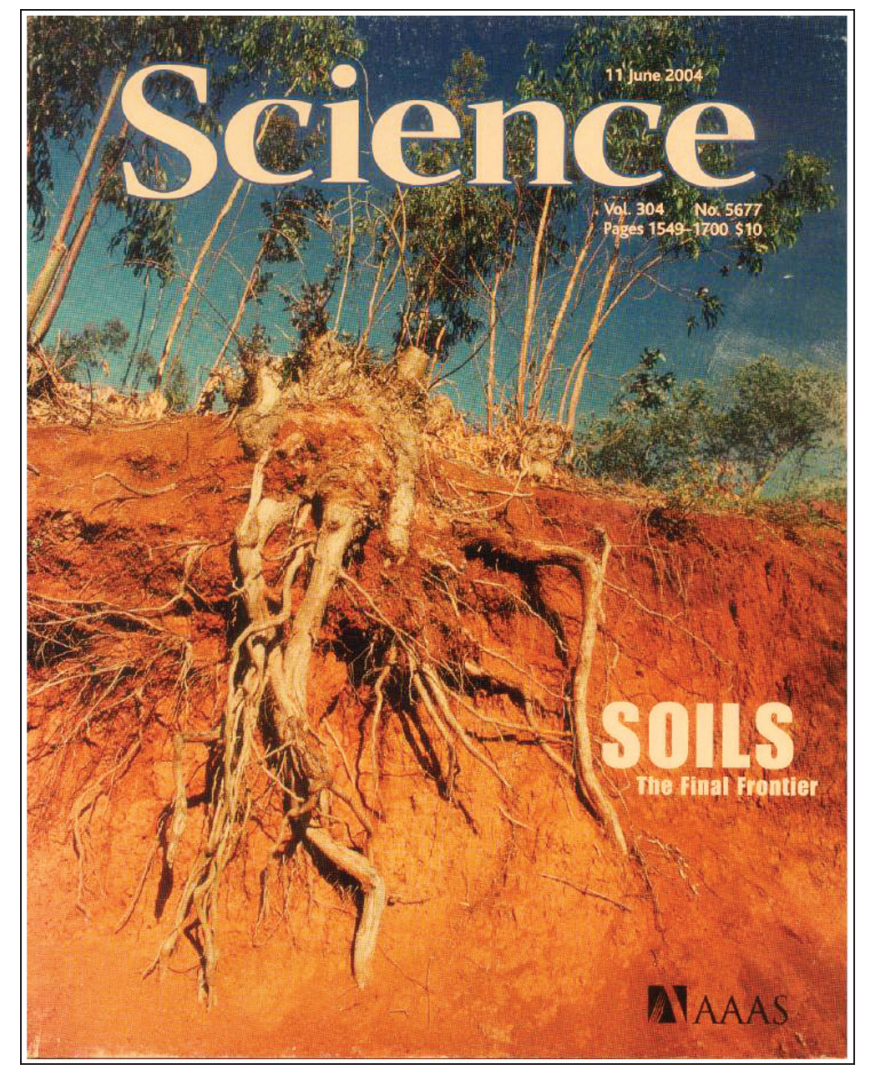

Fig. 1. "Soils: The final frontier": cover of the 11 June 2004, issue of the journal Science, containing eight articles related to soils. (The logo and text are reproduced with permission of the American Association for the Advancement of Science. The photograph is reproduced with the kind permission of Chinch Gryniewicz).

processes in the last $75 \mathrm{yr}$ since the founding of the SSSA, many aspects of soils still remain extremely elusive and poorly understood. These many persistent "islands of ignorance" are attributed to the extreme heterogeneity of soils at a wide range of spatial and temporal scales. Eventually, based on this analysis, we argue that references to soils, if not as the "final frontier", at least currently as a very important frontier of science, would be extremely helpful in terms of alerting public opinion about the significance of soils, to attract more students to the study of soils, and to affect policy-making related to soil degradation and conservation.

\section{SOILS AFFECT SOCIETY \\ Dust Bowls and Skinning of the Earth: Those Who Cannot Remember the Past...}

Santayana's (1905) famous saying that "those who cannot remember the past are condemned to repeat it" seems prophetic in the context of soils, because dust bowls have reappeared in the last decade, reminiscent of the 1930s. One of these dust bowls is located in China. Even though they were already suffering from overplowing and overgrazing, the north-western provinces of Inner Mongolia, Gansu, Qinghai, Ningxia, and Xinjiang, plowed ever more marginal lands after 1994, when a decision was made by the Chinese government to require that all cropland used for construction be offset by land reclaimed elsewhere (Yang and Li, 2000). Inner Mongolia led the way with a $22 \%$ cropland expansion. In addition, following economic reforms in 1978, livestock 


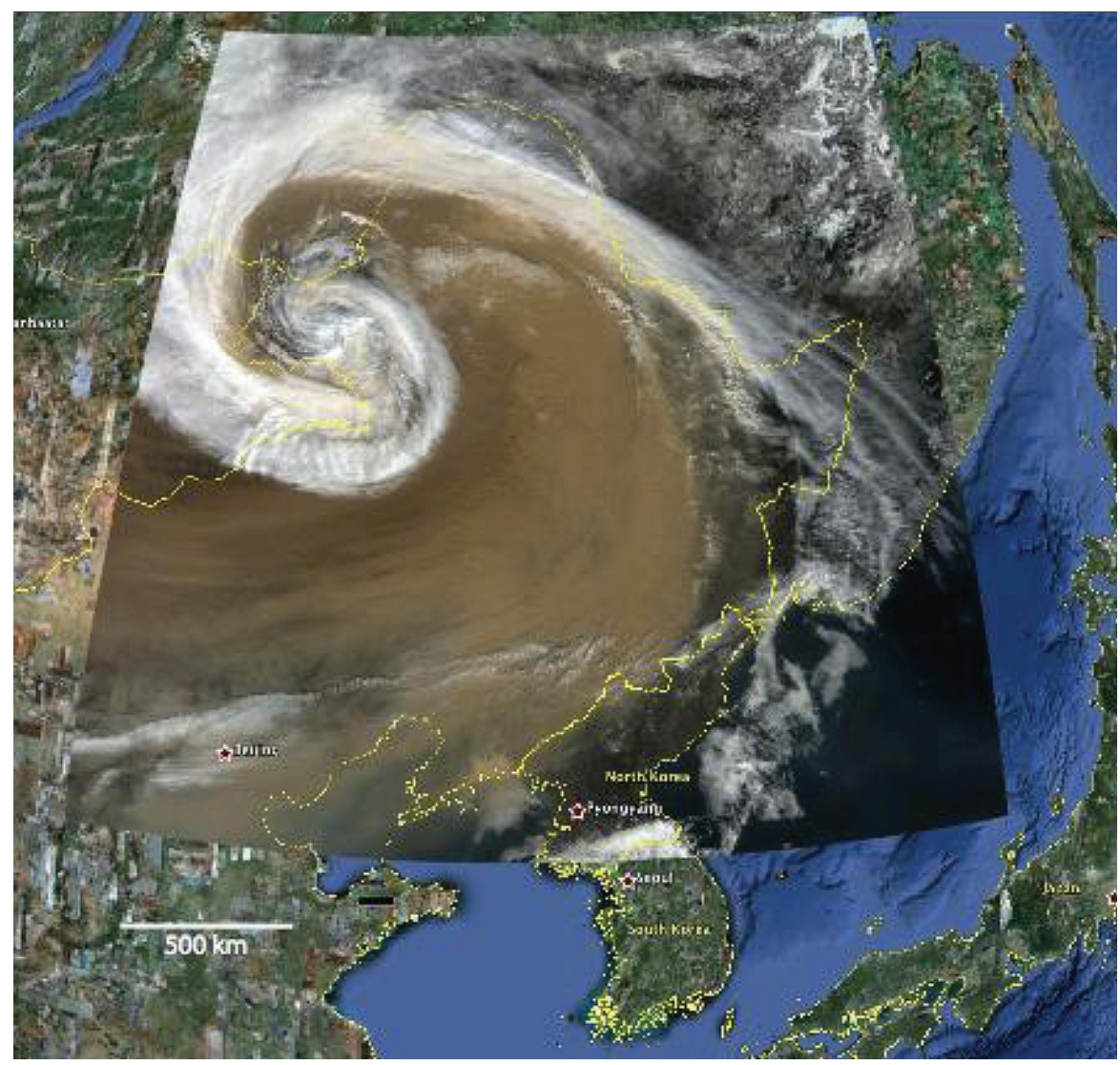

Fig. 2. Image captured by the Moderate Resolution Imaging Spectroradiometer (MODIS) on NASA's Terra satellite on 7 Apr. 2001, showing a massive dust storm being pushed ahead of a strong temperate cyclone spinning counter-clockwise over China. The tan-colored dust is thick enough to completely block out the land surface below. The dust cloud ultimately traveled across the Pacific Ocean to North America. Original image found at http://earthobservatory.nasa.gov/IOTD/view.php?id=8341 (accessed 10 June 2011, verified 20 Sept. 2011).

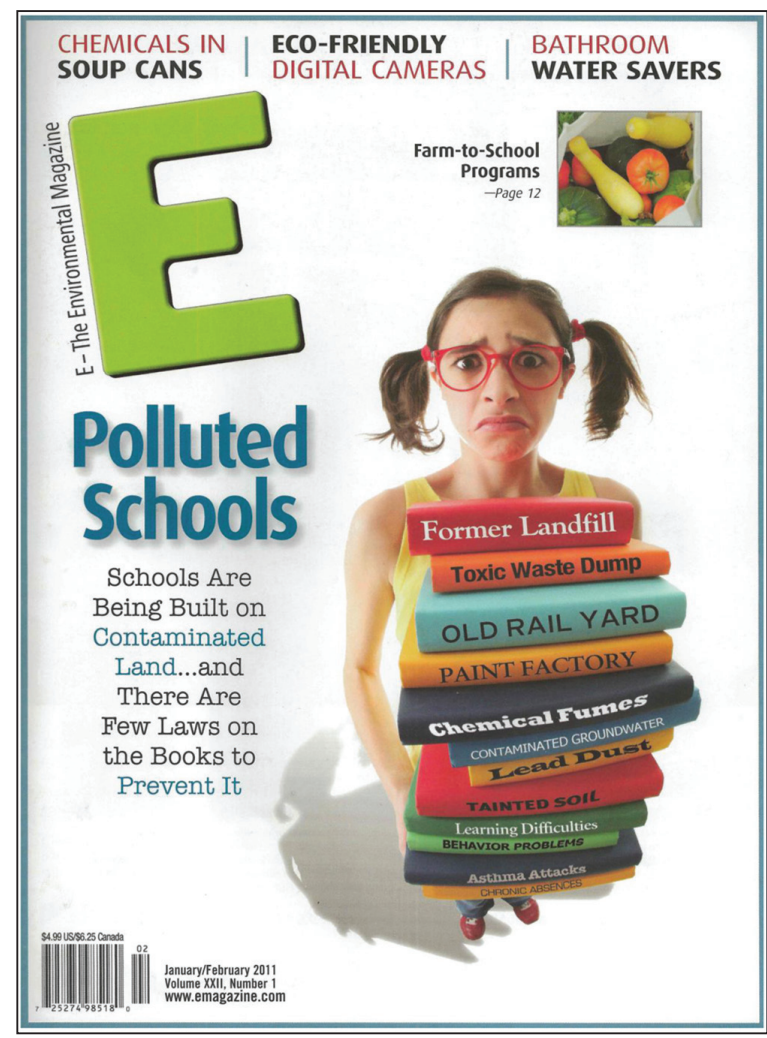

Fig. 3. Cover of the January/February 2011 issue of E-The Environmental Magazine. (Reproduced with permission of E-The Environmental Magazine). populations in the region have grown rapidly, often far beyond the land's carrying capacity. A direct result of these two trends is that soils have deteriorated, wind erosion has intensified, and the once infrequent, seasonal dust storms have become a far more common occurrence. In April 2001, one of the worst dust storms in memory hit Beijing (Fig. 2) then drifted eastward, eventually blanketing areas from Canada to Arizona with a layer of dust. Similar dust storms have continued since (Fig. 3). On 20 Mar. 2010, the first day of Spring, another massive sandstorm went from the arid terrain of Inner Mongolia to China. The yellow dust reduced visibility and air quality to potentially hazardous levels in the nation's capital, delaying flights at Beijing's airport and prompting a dust warning in Seoul, before it traveled as far away as Taiwan and Japan.

These dust storms, in China and elsewhere (e.g., Australia, U.S.), and the frequent brown plumes at estuaries, where sediment-laden river waters enter oceans, are unmistakable manifestations of soil erosion at a grand scale. Yet, as Montgomery (2007) argues, soil erosion is far more widespread than that. He estimates that we are now losing about $1 \%$ of our topsoil every year to erosion, most of this loss caused by agriculture, and that, in more ways than one, we are "running out of dirt". The evidence is everywhere that we are skinning the earth: "We see it in brown streams bleeding off construction sites and in sedimentchoked rivers downstream from clear-cut forests. We see it where farmers' tractors detour around gullies, where mountain bikes 
jump deep ruts carved into dirt roads, and where new suburbs and strip malls pave fertile valleys. This problem is no secret." (Montgomery, 2007). And if it gets worse still than it is at the moment, it could periodically bring air transportation to a halt, cause major health hazard, or make our rivers un-navigable.

Soil erosion is even increasingly affecting the world's traditional pollution sink: the oceans. In 2010 an explosion on an offshore drilling unit in the Gulf of Mexico resulted in the release of 670 thousand tons of crude oil over 3 mo that affected hundreds of kilometers of U.S. coastline and resulted in a maximum closure of $229,270 \mathrm{~km}^{2}$, or about $36 \%$ of the Gulf of Mexico, to fishing (Bluestein, 2010; NOAA, 2010; RestoreTheGulf.gov, 2010). This event is ranked among the greatest environmental disasters in U.S. history, and understandably dominated news reports and governmental releases for months. Receiving far less attention is a severe seasonal hypoxic zone in the Gulf of Mexico that lasts 5 to 6 mo of every year, affects on average $15,570 \mathrm{~km}^{2}$ (over the years 2005-2009) of important shrimp fishing areas, and has serious consequences for ecosystem functioning (Diaz and Rosenberg, 2008; CENR, 2010). This dead zone is caused in large part by high nutrient loads from the Mississippi River. Agricultural runoff is the major contributor releasing fertilizers, manure, pesticides, and sediment into the gullies, streams and waterways feeding the Mississippi. Despite soil conservation efforts that have reduced erosion to an average $9.75 \mathrm{Mg} \mathrm{ha}^{-1} \mathrm{yr}^{-1}$ across the entire Corn Belt, a study in Iowa has shown that the distribution is highly heterogeneous with rates of soil erosion in some townships exceeding $160 \mathrm{Mg} \mathrm{ha}^{-} \mathrm{yr}^{-1}$ (Cox et al., 2011). The Mississippi River/Gulf of Mexico Watershed Nutrient Task Force set a goal of reducing the size of the dead zone to $7921 \mathrm{~km}^{2}$, but with the exception of the Year 2000, the zone has increased in size every year since 1990 growing to an area the size of New Jersey by 2010 (Cox et al., 2011). As climate changes and the intensity of storms in the Mississippi watershed increase, reducing erosion might become even more challenging if not impossible, as suggested by the floods of May 2011. Alarmingly, the northern Gulf of Mexico dead zone is only one of more than 400 hypoxic zones worldwide occurring along the coasts of the continents and spreading over large areas of the sea floor (Diaz and Rosenberg, 2008), all contributed to by soil erosion and agricultural runoff that may originate hundreds of kilometers away. As if the challenge were not daunting enough, simulations of the hypoxic zone in the Gulf suggest that hypoxia will increase with climate change unless nutrient loads are reduced beyond current targets (Justiç et al., 2003).

\section{Soils and Climate Change}

Another avenue by which soils could very significantly affect society in years to come is related to global climate change. The importance of soils in this context should not be surprising. Indeed, soils are major players in the carbon cycle. Globally, world soils contain over $1550 \mathrm{Pg}$ of $\mathrm{C}$ in the surface meter alone (Baveye, 2007). This is more than twice the amount of carbon in the atmosphere. To put it differently, soils contain the equivalent of about 300 times the amount of $\mathrm{C}$ now released annually through the burning of fossil fuels. In addition, in many soils, $\mathrm{C}$ stocks contain large amounts of $\mathrm{N}$, whose metabolism by microorganisms can also contribute significantly to greenhouse gas emissions. Therefore, even small changes, of less than $1 \%$, of the amount of $\mathrm{C}$ contained in soils may lead to sources or sinks of greenhouse gases that could be significant relative to those released by fossil fuel combustion (Rustad et al., 2000). Increased release of carbon by world soils could drastically exacerbate atmospheric $\mathrm{CO}_{2}$ levels, leading to accelerated global warming and eventually to a positive feedback mechanism that might cause climate change to get completely out of hand (Baveye, 2007). However, attempts to sequester $C$ in soils by a variety of means, if they were successful, could have exactly the opposite effect. At this juncture, it is uncertain whether soils in temperate and tropical regions are likely to be net sources or sinks of greenhouse gases. Only in the high-latitude permafrosts, particularly in Siberia, is the situation more clear-cut in favor of a positive feedback to climate warming. Siberia has extensive areas $\left(10^{6} \mathrm{~km}^{2}\right.$, or roughly $11 / 2$ times the size of Texas), of deep (up to $90 \mathrm{~m}$ ) deposits of organic-rich frozen loess that accumulated during the Pleistocene. Their large organic C pool (roughly $450 \mathrm{Pg}$, more than half the amount of $\mathrm{C}$ in the atmosphere) has not been considered generally in most global C inventories (Zimov et al., 2006). Similar deposits occur less extensively in Alaska, where recent evidence suggests that permafrost is thawing at a much faster rate than previously anticipated. The organic $\mathrm{C}$ in these soils decomposes quickly on thawing, and is released to the atmosphere. Simultaneously, methane gas entrapped as large bubbles in the permafrost is released so fast that it prevents the surface from freezing, even in the midst of winter (Walter et al., 2006). Since methane is between 18 and 25 times more potent as a greenhouse gas than $\mathrm{CO}_{2}$, its release by permafrost is significant, at least in the short term (until methane is transformed into $\mathrm{CO}_{2}$ ).

The release or sequestration of greenhouse gases is not the only mechanism by which soils can have environmental effects in the event of global climate change. Experimental evidence (e.g., Qureshi et al., 2003a, 2003b) suggests that a general warming of ambient temperature may have an effect on the release and mobilization of heavy metals contained in soils, either naturally or artificially, for example as a result of the land application of sewage sludge.

\section{Urban Soils}

In recent years, the world population has become increasingly urbanized. There are large differences among countries, but on average, more than $50 \%$ of people live in urban or suburban areas, and this number is increasing constantly. In many cases, a consequence of this trend is that cities are expanding into what used to be their industrialized outskirts, where researchers have found that soils are routinely contaminated with a variety of organic and inorganic compounds. Even in the traditional city centers, contaminant levels in soils are often significantly elevated with historic pollutants such as lead from paint and gasoline, or polyaromatic hydrocarbons from vehicular exhaust or coal-fired 
power plant emissions (Belluck et al., 2003; Morillo et al., 2007). In recent years, the public at large has become more aware of potential problems associated with contaminant levels in urban soils, in part because contaminants are likely to affect children more directly, given the tendency of toddlers and infants to ingest significant amounts of soils through hand-to-mouth transfer when playing, for example in public parks. In a number of cities in the U.S. and Europe, parent associations have voiced serious concern about the financially motivated construction of daycare facilities and schools on former brownfields (Fig. 3). Even though soils at these sites may have been considered "clean" (i.e., with contaminant concentrations less than regulatory limits) at the time the buildings were erected, reports of noticeable emanations of volatile organic chemicals are causing parental concern over their children's exposure to chemicals that could affect their well-being and cognitive development (Weber, 2011).

\section{Soils and Food Security}

Perhaps surprisingly, food security comes last in this rapid overview of areas in which soils matter to society. Most authors would probably have broached this connection first, as by far the most important for soils. Countless articles in recent years (e.g., Pimentel et al., 2010) have commented on the causal relationship between decreases in per capita cropland and shortages of basic foods, especially as biofuel production begins to compete for available land.

Signs that, in the minds of most people, soils and food production are irrevocably connected are all around us. For example, a number of countries, particularly in Asia and the Middle East, faced with food supply problems in the coming decade, have in the last $10 \mathrm{yr}$ initiated major programs to purchase vast expanses of land in Africa and Latin America (Fig. 4). The global-scale "land grab" of unprecedented proportions that has unfolded has been studied very little in the academic literature to date (Robertson and Pinstrup-Andersen, 2010). Nevertheless, it seems clear that several relatively "land-rich" developing nations are sanctioning the sale or transfer of user rights of large tracts (sometimes millions of hectares) of farmland for foreign investment. Poor, smallholder farmers without formal land titles currently occupy much of the land leased or sold in these transactions, threatening the internal food security of the seller states. A further concern is that this land grab, particularly if it is associated with intensive agricultural practices in regions of the world like Sudan, Algeria, Madagascar, or Egypt, where water availability may be a significant issue at times, will lead to the same type of soil degradation that has afflicted northwestern China in the past decade, and that we will see many more dust bowls in the future, complete with local starvation, population migration, and compromised national and international security.

Is this direct link between soils and food security as tight as tradition leads one to believe? Although answering this question forces us to break away with millenia of soil-based farming, one could easily argue that the answer is negative and that, if one dares think "outside the box", a very different outlook is possible. From a resource allocation perspective, fully recognizing that water is as important, if not more important, to crop production than a soil material in which crops can propagate their roots, and that water will be scarce in many parts of the world in years to come,

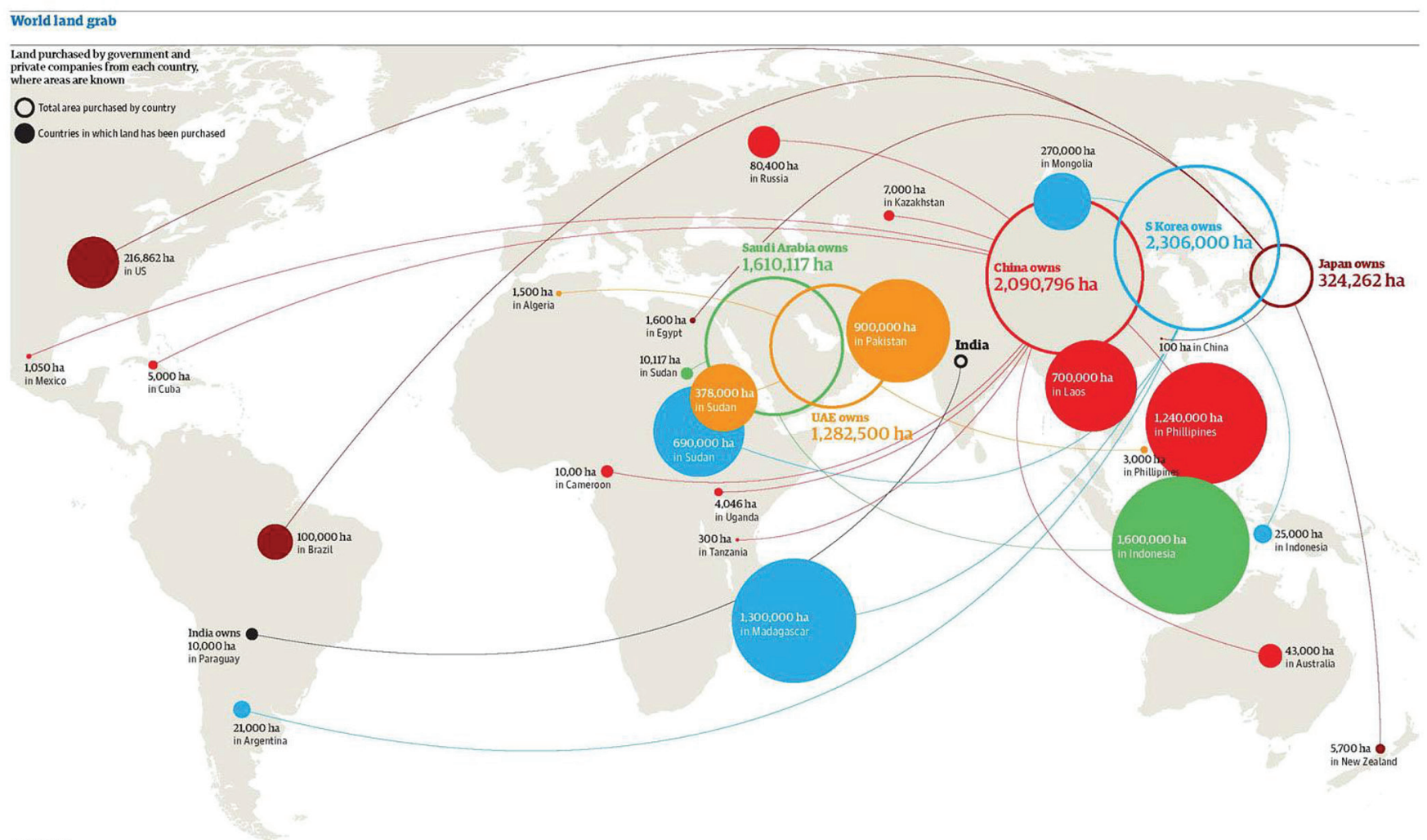

Fig. 4. Land grab around the world (Modified from a map published by The Guardian, using data from GRAIN, 2008). 
one would conclude that it would make sense to try to produce food where the water is. With the rare exception of countries, like Brazil, that are blessed with abundant water supplies, in general the requirement to go where the water is would force us naturally to turn to the oceans, which cover $71 \%$ of the Earth's surface and contain $97 \%$ of the planet's water. Roughly two thirds of the world population already live in coastal areas around the world, so that deriving food and energy from the oceans would not pose insurmountable logistic problems. In addition, Japan has shown, for centuries, that it is possible to derive sizeable quantities of food from oceans. Different types of seaweed, sea vegetables, and countless fish products, often not consumed in other countries, find their way in the daily diet of the Japanese population. This example has been emulated by China in the last 25 yr. Data compiled and reported by Liu and Diamond (2005) suggest that the production of aquacultured seafood has increased markedly since 1985 (Fig. 5). Some of the increase in production is associated with cultured freshwater operations, which most often use feed derived from land crops like soybeans and therefore do not change fundamentally the population's relationship with soils. However, of particular interest in Fig. 5 is the more than ten-fold increase in cultured marine production, in spite of the fact that China's coastal seas are polluted (Liu and Diamond, 2005).

Nothing would prevent other countries, with less polluted coastal ecosystems, to jump on the bandwagon and to produce
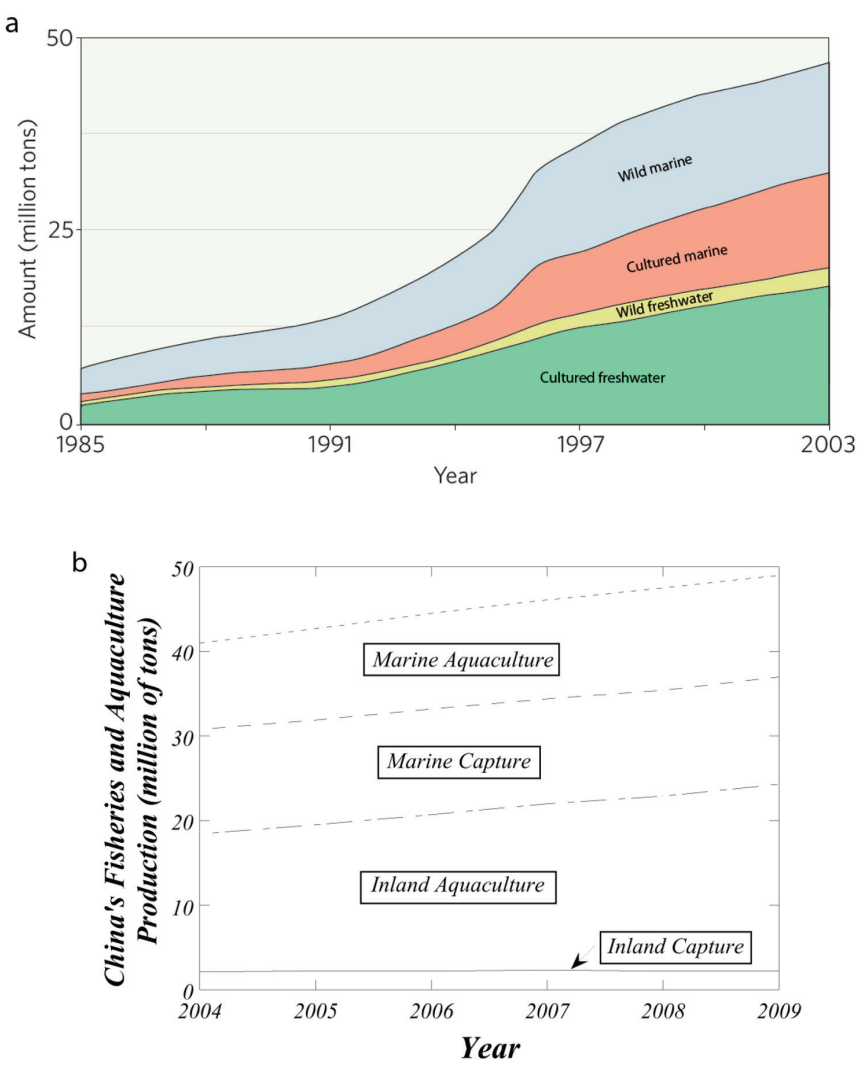

Fig. 5. Top: Evolution of China's aquatic production between 1985 and 2003. Data from Liu and Diamond (2005); Bottom: Evolution of the cumulative Chinese aquatic production between 2004 and 2009, divided into masses of inland capture, inland aquaculture, marine capture, and marine aquaculture. The original data are from FAO (2010). Data for 2009 are provisional estimates. in the oceans, if not human food, at least animal feeds or sea crops that could be eventually converted into biofuels. If this trend toward a more widespread seafarming (Radulovich, 2011) or mariculture materialized, soils would be less solicited for food production, and could be reforested to a far greater extent than at present, especially in erodable areas, or could be allowed more generally to be re-colonized by their natural vegetation. The significantly decreased soil degradation that would ensue would alleviate some of the problems mentioned earlier, including to a large extent (except in permafrost areas) the possible positive feedback of soils to climate change. To put things in more concrete terms, removal of the disproportionate food-security-related pressure currently exerted on soils, through a switch to mariculture, may prevent in the future some of the current environmental problems associated with mismanagement of soils, like dust bowls (Fig. 2). Of course, this would presuppose the ability to manage food and energy production in oceans in a sustainable fashion. In the past, this has not been the case, by far, as is obvious from the decline in numerous fish populations around the world. Nevertheless, perhaps in this case, things will be done carefully...

\section{SO MANY THINGS WE DO NOT KNOW, STILL...}

At the same time soils significantly affect human societies, there are still very many aspects of soils that we do not understand or that we grasp only superficially.

\section{Underestimating Soil Biota}

Perhaps the best illustration of how ignorant we still are, or, to be precise, still were $18 \mathrm{yr}$ ago about many soil processes, is the doom of the Biosphere II experiment in Arizona, initially conceived as an attempt to create a balanced and self-sustaining replica of Earth's ecosystems. By 26 Sept. 1993, when it became apparent after 18 mo of operation that the experiment had flopped, the 200 million dollars project had failed to meet many of its objectives. In particular, of the 25 small vertebrates with which the project began, only six did not die out by the mission's end. Almost all of the insect species were extinct, including those that had been included for the purpose of pollinating plants. But what really led to the demise of the project was the fact that oxygen concentration in the air could not be maintained at an appropriate level. There were several reasons for that, but one of the key ones, undoubtedly, was the fact that $\mathrm{O}_{2}$ consumption by soil microorganisms had been grossly underestimated by the experts involved. Especially in the rain forest and savanna areas of Biosphere II, soils were rich in organic matter. Microbes metabolized this material at an unexpectedly high rate, in the process using up a lot of $\mathrm{O}_{2}$ and producing significant amounts of $\mathrm{CO}_{2}$. Not quite 18 mo into the experiment, when oxygen levels dropped to the point where the crew could barely function, oxygen had to be pumped into the system so crew members could complete the full two year mission as planned. 


\section{Soil Biodiversity}

Far beyond the failure of Biosphere II, of course, microorganisms constitute a formidable challenge to anyone trying to understand soil processes, many of which in one way or another are mediated by, or at the very least involve, microorganisms. The identity of most of these microorganisms, however, remains largely a mystery. At this point, it is estimated that $99.5 \%$ of organisms in soils have not been cultivated (e.g., Gest, 2008; Zengler, 2009; Alain and Querellou, 2009). For a time, it seemed that metagenomics could dramatically change this picture, and provide a wealth of information about soil biota, while bypassing the need to cultivate the myriad of yet uncharacterized soil organisms. As some authors put it, "the blind survey of the streams of microbial sequences will undoubtedly facilitate the understanding of the mechanisms ruling the subterranean communities and bring exciting, unexpected discoveries" (Martin and Martin, 2010). Yet, the results to date are falling short of expectations. For instance, it remains unclear what percentage of the DNA present in soils is extracted by current techniques, and how representative this fraction is (Thakuria et al., 2008; Hjort et al., 2010; Trevors, 2009). This is clearly illustrated in a study by Ascher et al. (2009), who applied a novel DNA extraction protocol to two forest soils and observed that sequential extraction leads to increased DNA recovery, that extracellular DNA can represent a very sizeable (34.6\%) portion of the sum of extracellular and intracellular DNA, and that a very different perception of microbial diversity emerges if one considers the total extracted DNA or just the extracted intracellular DNA. Even if one could somehow resolve these DNA extraction problems, as well as the enormous computational "metagenome analysis gridlock" that has apparently taken microbiologists by surprise (Martin and Martin, 2010), it is still unclear whether metagenomics, without a suite of other "omics", like metabolomics or proteomics, can really shed light on soil biodiversity (Baveye, 2009; Singh et al., 2009). Indeed, some of the experts in the field recently admitted that it will be necessary in the near future to "develop and apply new approaches to cultivate the previously uncultivated and rare members of the soil community to assign functions to the vast number of unknown or hypothetical genes that will undoubtedly be found." (Vogel et al., 2009). So, in many ways, we are back to square one. The soil biodiversity challenge not only remains intact, but in some ways has grown.

\section{Carbon Sequestration in Soils}

Another issue about which considerable uncertainty persists concerns the practical conditions under which active $\mathrm{C}$ sequestration in soils could be feasible. Terrestrial $\mathrm{C}$ sequestration is often presented as a "win-win" situation to offset a substantial portion of anthropic $\mathrm{CO}_{2}$ emissions. $\mathrm{Lal}$ (2010), for example, claims that the technical potential of $\mathrm{C}$ sequestration in soils is roughly $3 \mathrm{Pg} \mathrm{C} \mathrm{yr}^{-1}$ or $50 \mathrm{ppm}$ drawdown of atmospheric $\mathrm{CO}_{2}$ by the end of the 21 st century, by increasing the soil $\mathrm{C}$ pool at a rate of $1 \mathrm{Mg} \mathrm{ha}^{-1} \mathrm{yr}^{-1}$. He suggested that this technical potential is as easily reachable as a "low-hanging fruit". Many disagree with this perspective (e.g., Baveye 2007; Govaerts et al., 2009; Sanderman and Baldock, 2010). For example, in a detailed analysis of the Upper Midwest region, often heralded as a prime candidate for large-scale C sequestration, Fissore et al. (2010) reach the conclusion that, in that region at least, "there is limited capacity for terrestrial C sequestration". These major differences of opinion among researchers about the feasibility of $\mathrm{C}$ sequestration appear caused in part by the extreme sensitivity of $\mathrm{C}$ accumulation toward the type of organic matter added to soils, as well as persistent questions about appropriate methodologies to sample soils (e.g., Senthilkumar et al., 2009; Syswerda et al., 2011).

Over the last decade, priming studies have demonstrated, time and again, that the simple addition of easily biodegradable $\mathrm{C}$ sources or even some plant litter to soils as a way to stimulate sequestration, could seriously backfire and actually lead to decreases in soil C (Fontaine et al., 2004). Fontaine et al. (2007), for example, have shown that the addition of glucose to soils containing various types of organic matter, including some estimated to be around 2500-yr old, resulted in the biodegradation of some of this ancestral organic matter, in addition to the added glucose. Similar results obtained by other researchers suggest that it may be tricky in practice to add organic matter in a way that does not cause more harm than good.

For a time, the adoption of no-tillage agricultural practices in agro-ecosystems was thought to be a realistic avenue for the sequestration of $\mathrm{C}$ in soils, and is still frequently touted as such (e.g., Lal, 2010). However, results obtained by, for example, VandenBygaart and Angers (2006), Baker et al. (2007), Yang et al. (2008), and Blanco-Canqui and Lal (2008) suggest that conclusions reached about the effectiveness of no-till depend strongly on how deep one is willing to dig to monitor SOM changes. When one samples deeper in the soil profile than the traditional 30 or $40 \mathrm{~cm}$, the alleged advantage of no-till over conventional tillage in terms of $\mathrm{C}$ sequestration disappears entirely or is even reversed in some cases. The existing experimental evidence concerning this issue was recently reviewed in detail by Luo et al. (2010). Using meta-analysis, these authors assessed the response of soil organic $\mathrm{C}$ to conversion of management practice from conventional tillage to no-tillage based on global data from 69 paired-experiments, where soil sampling extended deeper than $40 \mathrm{~cm}$. They found that cultivation of natural soils for more than $5 \mathrm{yr}$, on average, resulted in soil C loss of more than $20 \mathrm{Mg}$ $\mathrm{ha}^{-1}$, on average, with no significant difference between conventional tillage and no tillage. Overall, adopting no-tillage did not enhance soil total C stock down to $0.4 \mathrm{~m}$. Furthermore, Luo et al. (2010) found that increasing the number of crop species in rotation resulted in less $\mathrm{C}$ accumulation in the surface soil and greater $\mathrm{C}$ loss in deeper layers. On the other hand, a higher crop frequency seemed to have the opposite effect and significantly increased soil C by $11 \%$ in the $0-$ to $0.6-\mathrm{m}$ soil depth. Another aspect of the use of no-tillage in agroecosystems that has received significant attention recently is the fact that, fine-textured soils with seasonally high water contents, increased $\mathrm{N}_{2} \mathrm{O}$ emission may negate any beneficial effect of an increase in stored $\mathrm{C}$ ( $\mathrm{Li}$ et al., 2005; Powlson et al., 2011). 
Unresolved as well is the direct effect that $\mathrm{N}$ fertilizer additions have on $\mathrm{C}$ sequestration. This topic has been the object of a very lively debate over the last few years (see, e.g., Khan et al., 2007; Mulvaney et al., 2010a, 2010b; David et al., 2010; Powlson et al., 2010). A meta-analysis performed by Janssens et al. (2010) suggests that the deposition of biologically reactive $\mathrm{N}$ from the atmosphere impedes organic matter decomposition, and thus stimulates $\mathrm{C}$ sequestration, in temperate forest soils where $\mathrm{N}$ is not limiting microbial growth. On the other hand, Lu et al. (2011) recently completed a comprehensive meta-analysis of some 257 published studies and concluded that $\mathrm{N}$ addition resulted in no significant change of $\mathrm{C}$ storage in soils of forests and grassland, and only in a marginal (3.5\%) increase in agricultural ecosystems.

\section{Microheterogeneity of Soils}

In the last few years, researchers have begun to recognize that the physical and chemical microenvironments in which microorganisms proliferate and are metabolically active in soils are extremely heterogeneous at all spatial scales, particularly at the micrometric scale typical of many bacteria. Significant technological advances in recent years have provided soil researchers with routine access to $\mathrm{x}$-ray computed tomography systems, which once a number of roadblocks are resolved (e.g., Baveye et al., 2010b) will enable the geometry of pores and solids in soils to be visualized at resolutions as small as $0.5 \mu \mathrm{m}$. Concomitant progress in synchrotron-based microfluorescence spectroscopy and near-edge $x$-ray spectromicroscopy (NEXAFS) of thin sections of soils has led to observations of sharp differences in accumulation of trace metals (Jacobson et al., 2007) and chemical composition of the organic matter (Schumacher et al., 2005) in soils over minute distances, respectively of the order of nanometers to micrometers.

Simultaneously, comparisons between explicit pore-scale simulations and macroscopic continuum approximations have shown that inhomogeneous solute distribution within soil pores can significantly affect macroscopic estimates of elemental turnover rates, and that the error associated with large-scale rate estimates depends on the type of reaction, pore geometry, reaction kinetics, and macroscopic concentration gradient (Meile and Tuncay, 2006; Li et al., 2006). These experimental and modeling results raise a number of intriguing questions about the adequacy of the bulk averaged measurements of soil (bio)chemical properties that, at the moment, are routinely performed in wet-chemistry or microbiology laboratories around the world (Jacobson et al., 2007; Baveye, 2009), and on which current models of $\mathrm{C}$ and $\mathrm{N}$ dynamics in soils are based (Gras et al., 2010, 2011). It is clear that traditional measurements performed in soils, based on macroscopic volume or mass averages, are not satisfactory, and that they need to be complemented by other parameters, reflecting the level of microheterogeneity existing in the soils (Baveye, 2010). Further research is needed to determine how these parameters can be evaluated in practice. This issue is closely related to finding a proper conceptual way to reflect the macroscopic emergence of microscale heterogeneities in models of soil dynamics.

\section{SOILS ARE A CRUCIAL FRONTIER OF SCIENCE: WHY DOES IT MATTER?}

The various examples described and discussed in the preceding sections demonstrate that soil issues continue to be critical to the survival of mankind, let alone because even if floating cities ever develop, as some architects envision, most humans will still be in close contact with soils on a daily basis. Paradoxically, soils also remain, for the most part, very poorly understood, and the necessary research will be challenging in the foreseeable future. As a result, the case for soils to be viewed as "a" frontier of science would seem to be ironclad at this stage. This being said, one may wonder whether it makes any sense at this point to argue that case explicitly, and in particular to argue further that soils are "the" final frontier. To some, efforts along these lines may smack of sensationalism... To others, the concept itself of a final frontier may seem overblown, even in the context of the American psyche, where the notion of frontier has always, historically, occupied a very important place (Turner, 1935).

Be that as it may, there are very pragmatic reasons for soil scientists to promote the notion that soils are a very important, if not the most crucial, frontier of science. One key argument is that the public at large, as well as policymakers, tend to be oblivious of soil issues. In many respects, as Montgomery (2007) puts it, soils are our "most underappreciated, least valued, and yet essential natural resource." Unfortunately for soil scientists, this fascination with stars and disdain for stardust translates into minuscule financial resources allocated for the study of soils on earth relative to the "astronomical" funds allotted to space exploration. In the USA, for example, the annual budget of the National Aeronautics and Space Administration (NASA) was, as of 2010, in the vicinity of 19 billion dollars, roughly three times that of the National Science Foundation as a whole, and over eight times the research budget of the U.S. Department of Agriculture. Granted, some of the huge NASA budget covers costs associated with the launching into orbit of military payload satellites and a multitude of satellites meant to observe the earth, for example to monitor hurricanes or global climate change. However, a comparatively large portion of NASA's budget, and of the budgets of space agencies in other countries, relates to "deep space" exploration. For example, according to Wikipedia (http://en.wikipedia. org/wiki/List_of_space_telescopes), over the last $40 \mathrm{yr}, 90$ space telescopes, specifically meant to look outside the solar system, have been placed in orbit, at a cost varying between 50 and 400 million dollars per telescope, not including about 100 million dollars for each launch itself. Of these 90 telescopes, 28 are still in operation at the moment, requiring large teams of researchers and technicians to acquire, manipulate, and analyze the streams of data the telescopes provide. Nineteen more space telescopes are being built at the moment or are in the planning stages.

Among these space telescopes, a particular category has great significance in regards to soils. The mission of these telescopes, like the COROT, launched in 2006, or the Kepler spacecraft, launched in 2009, is to search for extrasolar planets, or "exoplanets", with short orbital periods, and to perform asteroseismology 
by measuring solar-like oscillations in stars. Kepler, specifically, has been searching for "Goldilocks planets" (planets of the right temperature to support liquid water) and has found large numbers of them in a targeted area of the sky, at distances varying from several hundred to a thousand light-years away from the earth.

Since the distances involved, and the enormous practical problems they raise for manned missions, make it extremely unlikely that humans could explore any of these exoplanets in even the distant future, appeals for financial support for the exploration of exoplanets are made on the grounds of how this exploration could benefit our current understanding of earth. Fridlund and Lammer (2010), for example, argue that "researchers will be able to place the Earth and the Solar System into the proper setting with regard to how worlds like our own form and evolve. Advances made by way of such a quest would undoubtedly lead to new fields of science, which would involve disciplines as widely disparate as biology, geophysics, and astronomy. Our newly acquired understanding would also allow for true comparisons to be made, and it would enhance our ability to draw conclusions as to how different circumstances lead to different evolutionary scenarios. The ultimate element of study, of course, would be the origin of life and its subsequent evolution, which could, in time, lead to a paradigm shift in our understanding of our genesis and the planetary environment within which we exist."

Regardless of how one views these arguments in favor of exoplanet exploration, it is mind-boggling that, as even the simplest "back-of-the-envelope" calculations suggest, significantly more money appears to be spent on exoplanets far away than on trying to directly study soils on earth! Leonardo da Vinci's viewpoint that "We know more about the movement of the celestial bodies than about the soil underfoot" seems as accurate now as it was $500 \mathrm{yr}$ ago, and is likely to remain that way unless something changes drastically. We could perhaps achieve a better balance in the financial support for research than is currently the case, if one promoted the idea that, for all practical purposes, soils are as final a frontier as we will ever get a chance to explore, if we do not succeed soon in managing them more sustainably.

A second reason for arguing the case that soils are a critical frontier of science, is that doing so will require researchers to publicize the fact that there are still many aspects of soils that we are only dimly aware of, or that remain extremely controversial. The soil science community in the past has not been keen to advertise its ignorance or to stimulate debates on contentious issues (Baveye, 2006; Baveye et al., 2006). This is understandable in the context of trying to convince skeptic audiences, for example groups of farmers in extension programs, that we know what we are talking about. However, a risk with such a portrayal is to make soil science appear boring and lackluster to prospective students, as if there were nothing left to discover about soils. This may in part explain the significant drops in enrollments in soil science in the last few years in most countries (Baveye, 2006; Baveye et al., 2006), with few exceptions (Baveye et al., 2010a; Camargo et al., 2010). In other disciplines, areas of uncertainties are debated much more openly. They appear to stimulate great enthusiasm and attract the best minds among the younger generations. For example, in physics, much has been said and written about the fundamental incompatibility of relativity and quantum theories, fostering significant interest in the development of a "grand unified" approach. Perhaps a campaign to promote soils as "the final" frontier could have a similar effect, in that prospective students, and the public at large, would realize how complex soils are, and how challenging some of the questions are that we are addressing about them.

\section{TAKE-HOME MESSAGE}

Seventy-five years ago, while the Soil Science Society of America (SSSA) was being created, soil dust was flying right and left in the continental USA, in one of the worst environmental disasters this country has ever experienced. This tragedy, which came to be known as the "Dust Bowl", could easily have been prevented. Indeed, even though many aspects of soils were still very poorly understood at the time, agronomists were well aware of the steps needed to prevent the massive erosion that caused the dust bowl. Greed on the part of land developers, ignorance on the part of many policymakers, and probably also the carelessness of many land managers unfortunately resulted in short-sighted decisions. Seventy five years later, we find ourselves in a very similar situation. Much progress has been made in our understanding of a wide range of soil processes. Yet, this knowledge does not always seem to be taken into account by decision makers, as is clearly the case in the various regions of the world that currently suffer from the same type of severe wind erosion as that of the 30's in the USA. In addition, in spite of all the progress made, there are still many aspects of soils about which little are known. In that sense, soils are still very much a frontier of science, as they were seven decades ago. Active emphasis of this "frontier" state of our discipline seems to be particularly appropriate at this time of shrinking financial support for scientific research across the board, and of dwindling enrollments in soil science programs in most countries.

\section{REFERENCES}

Alain, K., and J. Querellou. 2009. Cultivating the uncultured: Limits, advances and future challenges. Extremophiles 13:583-594. doi:10.1007/s00792009-0261-3

Albrecht, W.A. 1937. Minutes of the joint meeting. Soil Sci. Soc. Am. Proc. 1:505-526. doi:10.2136/sssaj1937.03615995000100000035x

Appleyard, B. 1995. A pinch of soil: The final frontier. The independent. Available at url: Http://www.independent.co.uk/opinion/a-pinch-of-soil-the-finalfrontier-1582047.html. (accessed 7 June 2011; verified 20 Sept. 2011).

Ascher, J., M.T. Ceccherini, O.L. Pantani, A. Agnelli, F. Borgogni, G. Guerri, P. Nannipieri, and G. Pietramellara. 2009. Sequential extraction and genetic fingerprinting of a forest soil metagenome. Appl. Soil Ecol. 42:176-181. doi:10.1016/j.apsoil.2009.03.005

Bainbridge, W.S. 2009. Space: The final frontier. Introduction. Futures 41:511513. doi:10.1016/j.futures.2009.04.022

Baker, J.M., T.E. Ochsner, R.T. Venterea, and T.J. Griffis. 2007. Tillage and soil carbon sequestration-What do we really know? Agric. Ecosyst. Environ. 118:1-5. doi:10.1016/j.agee.2006.05.014

Baveye, P. 2006. A future for soil science. J. Soil Water Conserv. 61:148A-151A. Baveye, P.C. 2010. Comment on "The role of scaling laws in upscaling" by B. D. Wood. Adv. Water Resour. 33:123-124. doi:10.1016/j. advwatres.2009.11.003

Baveye, P.C. 2007. Soils and runaway global warming: Terra incognita. J. Soil Water Conserv. 62:139A-143A. 
Baveye, P.C. 2009. To sequence or not to sequence the whole-soil metagenome? Nat. Rev. Microbiol. 7:756. doi:10.1038/nrmicro2119-c2

Baveye, P., A.R. Jacobson, S.E. Allaire, J. Tandarich, and R. Bryant. 2006. Whither goes soil science in the US and Canada? Survey results and analysis. Soil Sci. 171:501-518. doi:10.1097/01.ss.0000228032.26905.a9

Baveye, P., F.A.O. Camargo, and R. Poss. 2010a. The discipline of soil science is not doing too badly... under different skies. Soil Sci. 175:313-314. doi:10.1097/SS.0b013e3181e68c89

Baveye, P.C., M. Laba, W. Otten, L. Bouckaert, P. Dello Sterpaio, R.R. Goswami, D. Grinev, Y. Hu, J. Liu, S. Mooney, R. Pajor, S. Sleutel, A. Tarquis, W. Wang, Q. Wei, and M. Sezgin. 2010b. Observer-dependent variability of the thresholding step in the quantitative analysis of soil images and x-ray microtomography data. Geoderma 157:51-63. doi:10.1016/j. geoderma.2010.03.015

Belluck, D.A., S.L. Benjamin, P. Baveye, J. Sampson, B. Johnson, and M. Vogel. 2003. Widespread arsenic contamination of soils in residential areas and public spaces: An emerging regulatory or medical crisis? Int. J. Toxicol. 22:109-128. doi:10.1080/10915810305087

Blanco-Canqui, H., and R. Lal. 2008. No-tillage and soil-profile carbon sequestration: An on-farm assessment. Soil Sci. Soc. Am. J. 72:693-701. doi:10.2136/sssaj2007.0233

Bluestein, G. 2010. BP has another setback as oil slick threatens Florida. Associated Press. Cleveland Live, Inc., Cleveland, OH. Available at http:// www.cleveland.com/business/index.ssf/2010/06/bp_frees_saw_from_ pipe_oil_thr.html (accessed 7 June 2011; 20 Sept. 2011].

Cady, J.G., and K.W. Flach. 1997. History of soil mineralogy in the United States Department of Agriculture. Adv. GeoEcol. 29:211-240.

Camargo, F.A.D., V.H. Alvarez, and P.C. Baveye. 2010. Brazilian soil science: From its inception to the future, and beyond. Rev. Bras. Cienc. Solo 34:589-599. doi:10.1590/S0100-06832010000300001

Coleman, N.T., and M.E. Harward. 1953. The heats of neutralization of acid clays and cation-exchange resins. J. Am. Chem. Soc. 75:6045-6046. doi:10.1021/ja01119a510

Committee on Environment and Natural Resources (CENR). 2010. Scientific assessment of hypoxia in U.S. Coastal Waters. Interagency Working Group on Harmful Algal Blooms, Hypoxia, and Human Health of the Joint Subcommittee on Ocean Science and Technology. Washington, DC.

Cox, C., A. Hug, and N. Bruzelius. 2011. Losing ground. Environmental Working Group, Washington, DC. Available online at http://www.ewg. org/losingground. (Acessed 7 June 2011, verified 20 Sept. 2011).

David, M.B., G.F. McIsaac, and R.G. Darmody. 2010. Additional Comments on "Synthetic nitrogen fertilizers deplete soil nitrogen: A global dilemma for sustainable cereal production," by R.L. Mulvaney, S.A. Khan, and T.R. Ellsworth in J. Environ. Qual. (2009) 38:2295-2314. J. Environ. Qual. 39:1526-1527. doi:10.2134/jeq2010.0003le

Diaz, R.J., and R. Rosenberg. 2008. Spreading dead zones and consequences for marine ecosystems. Science 321:926-929. doi:10.1126/science.1156401

Egan, T. 2006. The worst hard time: The untold story of those who survived the great American dust bowl. Houghton Mifflin Company, New York.

Fissore, C., J. Espeleta, E.A. Nater, S.E. Hobbie, and P.B. Reich. 2010. Limited potential for terrestrial carbon sequestration to offset fossil-fuel emissions in the upper midwestern US. Front. Ecol. Environ 8:409-413. doi:10.1890/090059

Fontaine, S., G. Bardoux, L. Abbadie, and A. Mariotti. 2004. Carbon input to soil may decrease soil carbon content. Ecol. Lett. 7:314-320. doi:10.1111/ j.1461-0248.2004.00579.x

Fontaine, S., S. Barot, P. Barre, N. Bdioul, B. Mary, and C. Rumpel. 2007. Stability of organic carbon in deep soil layers controlled by fresh carbon supply. Nature 450(7167):277-280. doi:10.1038/nature06275

Food and Agriculture Organization. 2010. The state of the world fisheries and aquaculture 2010. Office of Knowledge Exchange, Research and Extension, Food and Agriculture Organization of the United Nations, Rome, Italy. Available online www.fao.org/docrep/013/i1820e/i1820e.pdf (accessed 10 June 2011; verified 20 Sept. 2011).

Fridlund, M., and H. Lammer. 2010. The astrobiology habitability primer. Astrobiology 10:1-4. doi:10.1089/ast.2009.0382

Genta, G., and M. Rycroft. 2006. Will space actually be the final frontier of humankind? Acta Astronaut. 58:287-295.

Gest, H. 2008. Unknowledgeables promote "unculturables". Microbe 3(11):499.
Govaerts, B., N. Verhulst, A. Castellanos-Navarrete, K.D. Sayre, J. Dixon, and L. Dendooven. 2009. Conservation agriculture and soil carbon sequestration: Between myth and farmer reality. Crit. Rev. Plant Sci. 28:97-122. doi: $10.1080 / 07352680902776358$

GRAIN. 2008. Seized: The 2008 land grab for food and financial security. Barcelona, Spain. Available at http://www.grain.org/briefings_files/ landgrab-2008-en.pdf. (Last accessed 4 July 2011, verified 20 Sept. 2011).

Gras, A., M. Ginovart, X. Portell, and P.C. Baveye. 2010. Individual-based modelling of carbon and nitrogen dynamics in soils: Parameterization and sensitivity analysis of abiotic components. Soil Sci. 175:363-374. doi:10.1097/SS.0b013e3181eda507

Gras, A., M. Ginovart, J. Valls, and P.C. Baveye. 2011. Individual-based modelling of carbon and nitrogen dynamics in soils: Parameterization and sensitivity analysis of bacterial components. Ecol. Modell. 222:19982010. doi:10.1016/j.ecolmodel.2011.03.009

Grim, R.E. 1968. Clay mineralogy. McGraw-Hill, New York.

Harper, H.J. 1937. Soil and civilization. Proc. Okla. Acad. Sci. 17:9-14. Available at http://digital.library.okstate.edu/oas/oas_pdf/v17/p9_14. pdf. (accessed 7 June 2011; verified 20 Sept. 2011).

Hendricks, S.B., and W.H. Fry. 1933. The results of $\mathrm{x}$-ray and mineralogical examination of soil colloids. Soil Sci. 29:457-476. doi:10.1097/00010694193006000-00003

Hillel, D. 1992. Out of the earth: Civilization and the life of the soil. University of California Press, Berkeley, CA.

Hjort, K., M. Bergstrom, M.F. Adesina, J.K. Jansson, K. Smalla, and S. Sjoling. 2010. Chitinase genes revealed and compared in bacterial isolates, DNA extracts and a metagenomic library from a phytopathogen-suppressive soil. FEMS Microbiol. Ecol. 71:197-207. doi:10.1111/j.15746941.2009.00801.x

Jacobson, A.R., S. Dousset, F. Andreux, and P.C. Baveye. 2007. Electron microprobe and synchrotron $\mathrm{x}$-ray fluorescence mapping of the heterogeneous distribution of copper in high-copper vineyard soils. Environ. Sci. Technol. 41:6350-6356. doi:10.1021/es0708159

Janssens, I.A., W. Dieleman, S. Luyssaert, J.-A. Subke, M. Reichstein, R. Ceulemans, P. Ciais, A.J. Dolman, J. Grace, G. Matteucci, D. Papale, S.L. Piao, E.-D. Schulze, J. Tang, and B.E. Law. 2010. Reduction of forest soil respiration in response to nitrogen deposition. Nat. Geosci. 3:315-322. doi: $10.1038 /$ ngeo8 44

Jenkins, A., H.S. Rong, V. Krutul, and M. Vara. 2007. Silicon lasers: The final frontier. Nat. Photonics 1:240-240. doi:10.1038/nphoton.2007.47

Joel, A.H. 1937. Conditions in the so-called dust bowl as revealed by a recent soil conservation survey. Soil Sci. Soc. Am. Proc. 1:343-344. doi:10.2136/ sssaj1937.03615995000100000061x

Justiç, D., N.N. Rabalais, and R.E. Turner. 2003. Simulated responses of the Gulf of Mexico hypoxia to variations in climate and anthropogenic nutrient loading. J. Mar. Syst. 42:115-126. doi:10.1016/S0924-7963(03)00070-8

Khan, S.A., R.L. Mulvaney, T.R. Ellsworth, and C.W. Boast. 2007. The myth of nitrogen fertilization for soil carbon sequestration. J. Environ. Qual. 36:1821-1832. doi:10.2134/jeq2007.0099

Krupenikov, I.A. 1993. History of soil science: From its inception to the present. AA Balkema, Rotterdam, The Netherlands.

Lal, R. 2010. Beyond Copenhagen: Mitigating climate change and achieving food security through soil carbon sequestration. Food Security 2:169-177. doi: 10.1007/s12571-010-0060-9

Li, C.S., S. Frolking, and K. Butterbach-Bahl. 2005. Carbon sequestration in arable soils is likely to increase nitrous oxide emissions, offsetting reductions in climate radiative forcing. Clim. Change 72:321-338. doi:10.1007/s10584-005-6791-5

Li, L., C.A. Peters, and M.A. Celia. 2006. Upscaling geochemical reaction rates using pore-scale network modelling. Adv. Water Resour. 29:1351-1370. doi: 10.1016/j.advwatres.2005.10.011

Liu, J.G., and J. Diamond. 2005. China's environment in a globalizing world. Nature 435(7046):1179-1186. doi:10.1038/4351179a

Lu, M., X.H. Zhou, Y.Q. Luo, Y.H. Yang, C.M. Fang, J.K. Chen, and B. Li 2011. Minor stimulation of soil carbon storage by nitrogen addition: A meta-analysis. Agric. Ecosyst. Environ. 140:234-244. doi:10.1016/j. agee.2010.12.010

Luo, Z.K., E.L. Wang, and O.J. Sun. 2010. Can no-tillage stimulate carbon sequestration in agricultural soils? A meta-analysis of paired experiments. Agric. Ecosyst. Environ. 139:224-231. doi:10.1016/j.agee.2010.08.006 
Marbut, C.F. 1935. Soils of the United States. Atlas of American Agriculture. USDA, Washington, DC

Marrin, A. 2009. Years of dust. Dutton Juvenile, New York.

Martin, N.F., and F. Martin. 2010. From Galactic archeology to soil metagenomics-Surfing on massive data streams. New Phytol. 185:343348. doi:10.1111/j.1469-8137.2009.03138.x

Mattson, S. 1929. The laws of soil colloidal behavior I. Soil Sci. 28:179. doi:10.1097/00010694-192909000-00001

McDunn, R. 2007. The green coat: A tale from the dust bowl years. Belazel Books, New York.

Meile, C., and K. Tuncay. 2006. Scale dependence of reaction rates in porous media. Adv. Water Resour. 29:62-71. doi:10.1016/j.advwatres.2005.05.007

Montgomery, D.R. 2007. Dirt: The erosion of civilizations. University of California Press, Berkeley, CA.

Morillo, E., A.S. Romero, C. Maqueda, L. Madrid, F. Ajmone-Marsan, H. Greman, C.M. Daidson, A.S. Hursthouse, and J. Villaverde. 2007. Soil pollution by PAHs in urban soils: A comparison of three European cities. J. Environ. Monit. 9:1001-1008. doi:10.1039/b705955h

Mulvaney, R.L., S.A. Khan, and T.R. Ellsworth. 2010a. Comments on "Synthetic nitrogen fertilizers deplete soil nitrogen: A global dilemma for sustainable cereal production," by R.L. Mulvaney, S.A. Khan, and T.R. Ellsworth. J. Environ. Qual. 39:753-756.

Mulvaney, R.L., S.A. Khan, and T.R. Ellsworth. 2010b. Reply to Additional Comments on "Synthetic nitrogen fertilizers deplete soil nitrogen: A global dilemma for sustainable cereal production," by R.L. Mulvaney, S.A. Khan, and T.R. Ellsworth. J. Environ. Qual. 39:1530-1532.

NOAA. 2010. Deepwater Horizon/BP Oil Spill: Size and Percent Coverage of Fishing Area Closures Due to BP Oil Spill. NOAA, National Marine Fisheries Service, Southeast Regional Office. Table. Available online at http://sero.nmfs.noaa.gov/ClosureSizeandPercentCoverage.htm (accessed 7 June 2011; verified 20 Sept. 2011).

Paungfoo-Lonhienne, C., D. Rentsch, S. Robatzek, R.I. Webb, E. Sagulenko, T. Nasholm, S. Schmidt, and T.G.A. Lonhienne. 2010. Turning the table: Plants consume microbes as a source of nutrients. PLoS ONE 5:e11915. doi;doi:10.1371/journal.pone.0011915

Pimentel, D., M. Whitecraft, Z.R. Scott, L. Zhao, P. Satkiewicz, T.J. Scott, J. Phillips, D. Szimak, G. Singh, D.O. Gonzalez, and T.L. Moe. 2010. Will limited land, water, and energy control human population numbers in the future? Hum. Ecol. 38:599-611. doi:10.1007/s10745-010-9346-y

Powlson, D.S., A.P. Whitmore, and K.W.T. Goulding. 2011. Soil carbon sequestration to mitigate climate change: A critical re-examination to identify the true and the false. Eur. J. Soil Sci. 62:42-55. doi:10.1111/ j.1365-2389.2010.01342.x

Powlson, D.S., D.S. Jenkinson, A.E. Johnston, P.R. Poulton, M.J. Glendining, and K.W.T. Goulding. 2010. Reply to additional comments on "Synthetic nitrogen fertilizers deplete soil nitrogen: A global dilemma for sustainable cereal production," by R.L. Mulvaney, S.A. Khan, and T.R. Ellsworth. J. Environ. Qual. 39:1528-1529.

Qureshi, S., B.K. Richards, A.G. Hay, M.B. McBride, P. Baveye, C.C. Tsai, and T.S. Steenhuis. 2003a. Effect of microbial activity on trace metals released from sewage sludge. Environ. Sci. Technol. 37:3361-3366. doi:10.1021/ es020970h

Qureshi, S., B.K. Richards, M.B. McBride, P. Baveye, and T.S. Steenhuis. 2003b. Biological release and leaching of trace elements from metalliferous peat affected by temperature. J. Environ. Qual. 32:2067-2075. doi:10.2134/ jeq2003.2067

Radulovich, R. 2011. Massive water savings from producing food at sea. Water Policy J. 13:547-554. doi:10.2166/wp.2011.137

Ramanathan, N., T. Schoellhammer, D. Estrin, M. Hansen, T. Harmon, E. Kohler, and M. Srivastava. 2006. The final frontier: Embedding networked sensors in the soil. Tech. Rep., Center for Embeddded Network Sensing, University of California at Los Angeles, Los Angeles, CA. Available online at: Http://escholarship.org/uc/item/28v8b7c9 (accessed 7 June 2011, verified 20 Sept. 2011).

RestoreTheGulf.gov. 2010. One year later press pack. Available at http:// www.restorethegulf.gov/release/2011/04/10/one-year-later-press-pack (accessed 7 June 2011; verified 20 Sept. 2011).
Robertson, B., and P. Pinstrup-Andersen. 2010. Global land acquisition neocolonialism or development opportunity? Food Security 2:271-283. doi:10.1007/s12571-010-0068-1

Rustad, L.E., T.G. Huntington, and R.D. Boone. 2000. Controls on soil respiration: Implications for climate change. Biogeochemistry 48:1-6. doi:10.1023/A:1006255431298

Sanderman, J., and J.A. Baldock. 2010. Accounting for soil carbon sequestration in national inventories: A soil scientist's perspective. Environ. Res. Lett. 5:034003 doi: $10.1088 / 1748-9326 / 5 / 3 / 034003$.

Santayana, G. 1905. Reason in common sense. The life of reason. Vol. 1. Dover Publications, NY.

Schumacher, M., I. Christl, A.C. Scheinost, C. Jacobsen, and R. Kretzschmar. 2005. Chemical heterogeneity of organic soil colloids investigated by scanning transmission $\mathrm{x}$-ray microscopy and C-1s NEXAFS microspectroscopy. Environ. Sci. Technol. 39:9094-9100. doi:10.1021/ es050099f

Senthilkumar, S., B. Basso, A.N. Kravchenko, and G.P. Robertson. 2009. Contemporary evidence of soil carbon loss in the US corn belt. Soil Sci. Soc. Am. J. 73:2078-2086. doi:10.2136/sssaj2009.0044

Singh, B.K., C.D. Campbell, S.J. Sorenson, and J. Zhou. 2009. Soil genomics. Nat. Rev. Microbiol. 7:756. doi:10.1038/nrmicro2119-c1

Sugden, A., R. Stone, and C. Ash. 2004. Ecology in the underworld: Introduction. Science 304(5677):1613-1613. doi:10.1126/science.304.5677.1613

Syswerda, S.P., A.T. Corbin, D.L. Mokma, A.N. Kravchenko, and G.P. Robertson. 2011. Agricultural management and soil carbon storage in surface vs. deep layers. Soil Sci. Soc. Am. J. 75:92-101. doi:10.2136/sssaj2009.0414

Thakuria, D., O. Schmidt, M. Mac Siurtain, D. Egan, and F.M. Doohan. 2008. Importance of DNA quality in comparative soil microbial community structure analyses. Soil Biol. Biochem. 40:1390-1403. doi:10.1016/j. soilbio.2007.12.027

Trevors, J.T. 2009. One gram of soil: A microbial biochemical gene library. Antonie Van Leeuwenhoek Int. J. General Mol. Microbiol. 97:99-106. doi:10.1007/s10482-009-9397-5

Turner, F.J. 1935. The frontier in American history. Henry Holt and Company, NY.

United States Department of Agriculture. 1938. Soils and men: Yearbook of agriculture. USDA, Washington, DC.

VandenBygaart, A.J., and D.A. Angers. 2006. Towards accurate measurements of soil organic carbon stock change in agroecosystems. Can. J. Soil Sci. 86:451-463. doi: 10.4141/S05-105

Vogel, T.M., P. Simonet, J.K. Jansson, P.R. Hirsch, J.M. Tiedje, J.D. van Elsas, M.J. Bailey, R. Nalin, and L. Philippot. 2009. Terragenome: A consortium for the sequencing of a soil metagenome. Nat. Rev. Microbiol. 7:252-252. doi: $10.1038 /$ nrmicro2119

Waksman, S.A. 1936. Humus: Origin, chemical composition, and Importance in nature. The Williams \& Wilkins Company, Baltimore, MD.

Wallace, M.B., T.A. Woodward, M. Raimondo, M. Al-Haddad, and J.A. Odell. 2007. Transaortic fine-needle aspiration of centrally located lung cancer under endoscopic ultrasound guidance: The final frontier. Ann. Thorac. Surg. 84:1019-1021. doi:10.1016/j.athoracsur.2007.03.012

Walter, K.M., S.A. Zimov, J.P. Chanton, D. Verbyla, and F.S. Chapin. 2006. Methane bubbling from Siberian thaw lakes as a positive feedback to climate warming. Nature 443(7107):71-75. doi:10.1038/nature05040

Weber, C. 2011. Dirty secrets under the schoolyard: Parents demand new curbs for schools built on contaminated land. E-Magazine 22(1):22-28.

Yang, H., and X.B. Li. 2000. Cultivated land and food supply in China. Land Use Policy 17:73-88. doi:10.1016/S0264-8377(00)00008-9

Yang, X.M., C.F. Drury, M.M. Wander, and B.D. Kay. 2008. Evaluating the effect of tillage on carbon sequestration using the minimum detectable difference concept. Pedosphere 18:421-430. doi:10.1016/S1002-0160(08)60033-8

Zengler, K. 2009. Central role of the cell in microbial ecology. Microbiol. Mol. Biol. Rev. 73:712-729. doi:10.1128/MMBR.00027-09

Zimov, S.A., S.P. Davydov, G.M. Zimova, A.I. Davydova, E.A.G. Schuur, K. Dutta, and F.S. Chapin. 2006. Permafrost carbon: Stock and decomposability of a globally significant carbon pool. Geophys. Res. Lett. 33:L20502. doi:10.1029/2006GL027484 